\title{
A COGNITIVE APPROACH TO TRADITIONAL ORAL POETRY: FRAMES AND SCRIPTS IN THE JEBLI AYYU
}

\author{
Sarali GINTSBURG ${ }^{\star}$ \\ University of Navarra
}

BIBLID [1133-8571] 26 (2019) 17.1-23.

\begin{abstract}
In this paper I continue to examine the oral tradition of the Jbala (northern Morocco) from the cognitive perspective. I use the notions of frame (topics or scenes) and script (formulaic language), to demonstrate how the process of poetic creation works in actual time. For this purpose, I propose to look at the genre of ayyu, a short improvised oral poetic genre intrinsic to the Jbala region. I start with an introductory section, where I briefly present the field of cognitive poetics, relevant terminology used by scholars working in this field, and discuss last advances in it. Then I turn to the oral poetry of the Jbala and demonstrate how exactly frames and scripts operate when poetry is performed live. Further, I analyze in detail several frames, typical of Jebli poetry together with the scripts associated with them, and then summarize my findings in the concluding section of the paper.
\end{abstract}

Key words: Arabic language, Morocco, Cognitive linguistics, Frames, Scripts, Formulaic language.

Resumen: En este artículo presentamos la tradición oral de la región de Jbala (norte de Marruecos) desde una perspectiva cognitiva. Empleamos las nociones de «marco» (temas o escenas) y «guión» (lenguaje formulaico) para demostrar cómo funciona el proceso de creación poética en tiempo real. Nos centraremos en el género de $a y y u$, un género de poesía oral corta, improvisada y autóctona de la región de Jbala. Empezaremos introduciendo brevemente el campo de la poética cognitiva, su terminología más relevante y los últimos avances. Después presentamos la poesía oral de la región de Jbala y examinamos cómo funcionan los «marcos» y los «guiones» en la poesía cantada. Asimismo, analizamos en detalle varios «marcos» típicos de la poesía jebli junto con los «guiones» asociados a ellos para terminar con unas conclusiones en las que presentamos nuestros hallazgos.

Institute for Culture and Society. E-mail: sgintsburg@unav.es. 
Palabras clave: Lengua árabe, Marruecos, Linguística cognitiva, Marcos, Guión, Lenguaje formulaico.

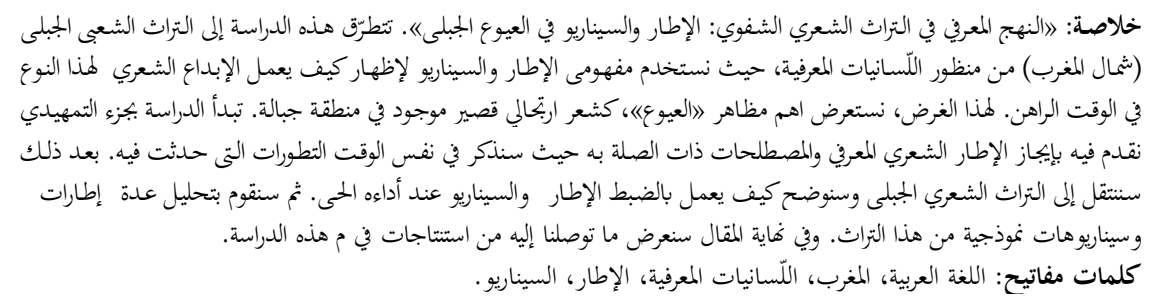

\section{Introduction}

The first attempts to interpret from the cognitive viewpoint how we humans handle information were made by Bartlett (1932), and later developed by Minsky (1975) and Fillmore (1982), who suggested that the human mind operates with the help of frames, systems of basic concepts, situations or events that allow us to establish relations between a number of characteristics and, therefore, build mental models of the world. The notion of frame is inseparably associated with the principle of continuity between language and experience: the speaker applies a frame to context and makes this frame «visible» to others by using words associated with this particular frame that index the expectations that both speaker and audience have in relation to that particular frame. The cognitive structures associated with a frame are partially fixed, but they also have open slots in them that can be filled with more specific information. These slots can also be used as links that connect different frames together to build so called frame systems (Minsky 1975). In parallel to the theory of frames was developing the theory of scripts. Just as with frames, the idea of scripts evolves around concepts and events, but if frames play the role of topics, scripts represent «a predetermined, stereotyped sequences of actions that defines a well-known situation» (Schank \& Abelson 1977: 43). In other words, if frame is more general and stable, often manifested in a concept that can be encapsulated in one or two words, a script is a detailed story made of several episodes.

Some of these ideas were adopted first by experts in cognitive poetics and, more recently, experts in cognitive oral poetics with the purpose of gaining a clearer understanding of literary text, both in its oral and written forms, and of 
glimpsing the complex cognitive processes behind its creation. Researchers adapted some of the key concepts to literary material, first of all focusing on schemas (Cook 1994, Cockroft 2002 and Steen 2003) and frames (Stockwell 2002) that correspond to themes and topics, and constructions - which correspond to poetic formulas (Boas 2016 and Bozzone 2014). This research, however, always treated either authored written literary texts (Stockwell 2002), or already vanished oral traditions, principally Greek epics, which are not extant in their original, i.e., oral, form (see, for instance, Bozzone 2014). In my recent research I used the modern tradition of the ayyu (Jbala, northern Morocco) to demonstrate how these cognitive concepts may function in a living improvised oral poetic tradition (Gintsburg 2017 and Gintsburg 2019).

In this paper I will continue to test some of the findings from the previous research I discussed above on the oral tradition of the Jbala. The tradition of the Jbala is substantially different from the materials used by other experts in cognitive poetics - on the one hand, it is oral and often unauthored, on the other hand, their poems are typically very short. However, it represents extremely interesting material for research of this kind because it is produced on the spot and, therefore, is (1) oral, and (2) improvisational, i.e., it can be seen as a minimodel reflecting features of human everyday speech but within a specific, learned genre. Consequently, I assume that when Jebli poets produce their improvised verses, by and large, the same cognitive mechanisms described by cognitive linguists on the material of everyday speech are involved. In addition, the Jebli oral tradition belongs to lyric poetry, i.e., short verse, which does not allow for any complex stories. Moreover, unlike epic poetry, the traditional Jebli poetry, in general, very seldom tells any story at all, but rather is allusive in the sense that it describes emotions and situations. In other words, I assume that even when a poet works in a genre that does not allow full development of a story and, hence, does not offer the poet space to make a full use of a frame, the poet still alludes to frames, and in fact, the limitations intrinsic to this genre make the use of frames and scripts even more necessary in order for him/her to achieve communication with his/her audience. In order to test this assumption, in this article I aim to demonstrate how exactly frames and scripts are realised in the ayyu genre.

There have been earlier attempts to classify Jebli poetry based on motifs and themes (Gintsburg 2006, Moscoso 2015a, 2015b and 2017c). However, research on the oral tradition of the Jbala has been mostly conducted using what can be called a traditional, classical approach: the primary goal of those who worked with it was 
limited to, first and foremost, collecting poetic texts, transcribing and translating them and then analysing their language and structure, which included discussing the literary tropes, and specific aspects of rhyme pattern and syllabic structure of Jebli poetry. An initial attempt to approach this living oral tradition by applying to it both classical philological and linguistics criteria was made in Formulaicity in the Jbala poetry (Gintsburg 2014), where the oral tradition of the Jbala was treated in all its complexity: in this study poetic text is treated as an integral part of performance, in which components such as poetry, music and sequence of performance are suggested to be of equal importance. In my subsequent publications «It's got some meaning but I am not sure...: The role of the particle (wa)-ma in the oral and transitional poetry of the Jbala (northern Morocco) from the cognitive perspective» (Gintsburg 2017) and «Lost in dictation. A cognitive approach to oral poetry: Frames, scripts and 'unnecessary' words in the Jebli ayyu» (Gintsburg 2019) another step forward was made - I analysed the Jebli oral tradition using an innovative methodology: i.e., by applying the notion of frames and scripts, in order to provide a cognitive perspective that would complement the traditional approach to oral poetry.

\section{Material (Tradition)}

The term Jbala (from Moroccan Arabic jbāl, «mountains») is conveniently used to define people inhabiting the north-western, Arabic-speaking part of the Rif mountains. The natives of the Jbala area are known for being diverse: they belong to various tribes and tribal confederations and speak distinct varieties of Jebli dialects of Moroccan Arabic. However, they still have much in common: despite differences, their dialects and lifestyle have a lot of similarities, and their oral tradition is strikingly different both from oral traditions existing in the rest of Morocco (both Arabic and Amazigh-speaking), and from those found in the rest of the Arab world. Below I introduce and discuss the $a y y u$, one of the oral genres of the Jebli poetic tradition that became a focus for this research. There are three genres of the poeticomusical art of the Jbala area: ayta, ayyu and ughniya. They share a lot stylistically and textually and, hence, contain a fair amount of the same poetic vocabulary. This study, however, focuses on only one of these genres, namely, the ayyu, which I describe below.

Ayyu (ع عayyū \&, origin unknown) is performed during seasonal pilgrimages to the shrines of the numerous local saints, where visitors from different Jbala tribes take turns to sing short verses, usually of a religious character. Аyyu is always sung to the same tune, and does not have any preludes 
or choruses. Although ayyu is traditionally regarded as a feminine genre, it is also performed by men, as long as they can reach very high notes. Аyyu is also often sung while women perform their daily chores, such as washing clothes at a water spring, sewing, knitting and collecting wood, or during various agricultural festivities. While working, women start what can be called a dialogue, or poetic duel: one of them commences with a short verse and then somebody else has to respond with a new verse in a similar manner. Topics can be anything from harvesting to romance and humour. Due to its nature, ayyu has traditionally been and still remains an oral genre. Although it is a typical work song performed by amateurs, it is not uncommon for professional Jebli poets and singers to include series of ayyu verses into their performance and interweave them with pieces belonging to other genres. It probable that the genre of ауyи has Rifian or, perhaps, general Amazigh origins, although, as far as I know, no comparative research has been carried out to clarify this matter ${ }^{(1)}$.

Typically, an ауyи is a poetic quatrain, which in Arabic tradition is called a beyt. Poetic requirements for a Jebli beyt reflect the most essential principles typical of Arabic poetry in general. These requirements, however, are less rigid and, by and large, a Jebli beyt only vaguely reminds us of a beyt in its classical form. A Jebli beyt consists of four lines, where lines 2 and 4 are always rhymed, while rhyming lines 1 and 3 is not compulsory. Unlike in Classical or modern Bedouin Arabic poetry, the Jebli verse knows no poetic metre to follow. It is always sung, and in the case of ayyu it is most often performed solo, or sometimes accompanied by the ghayta, or Moroccan oboe. It seems that participation of an oboist in live exchanges of ayyu plays at least two roles: first, it enriches the performance by making it sound more like a complete musical piece and, second, it allows the participants to take breaks and prepare for the next round of poetic dialogue. In other words, the ayyu relies heavily on melody and is never recited but always sung. Some ayyus can consist of only 2 or 3 lines, but such cases are fairly rare. Ayyus, with the exception of some regional variations, are always sung using the same tune. An ayyu performer chooses the tune she/he prefers and typically sticks to it. Normally, a live

(1) See, for instance, García Ruda's description of the oral tradition of Rifian Amazighs living in the Guelaya region (García Ruda 2016: 131-132). 
performance of ауyи also involves using extra lines that are most often uttered at the end of the quatrain, but can also break it into two halves ${ }^{(2)}$.

One might argue that this type of material, due to its brevity, would not constitute a solid base for performing research on the cognitive aspect of composition-in-performance. Indeed, all previous research focused on lengthy pieces of poetry, such as Homeric epic, that are characterised by complex plots and demand that oral poets create under «cognitive pressure» (De Kreij 2016: 149). I would object, however, that the key words here would be «create in performance» and «communicate» rather than «stress» or «pressure».

This study is conducted on the collection of quatrains collected during the first half of the 20th century by the self-taught Spanish ethnographer Pereda. These quatrains were archived for almost forty years and only recently rediscovered, edited and published together with a philological commentary by Moscoso (2014). I prefer to identify these quatrains as ayyu because of the way they were collected by PEREDA, i.e., as independent texts, although these quatrains could also be used (and, in fact, they are) in other, lengthier Jebli genres, such as ayta and ughniya (Gintsburg 2014). Occasionally, I will also refer to my own previously collected and partially published material (Gintsburg 2005, 2006 and 2014). To «decipher» the meaning of these quatrains, which is often not obvious without solid ethnographic knowledge of the everyday culture of the Jbala people, I will rely on my own experience, as well as on valuable work by Westermarck (1914, 1926 and 1931), Michaux-Bellaire (1911), Biarnay (1924) and Salmon (1904). Similarly, I will be regularly referring to the dictionary of Moroccan Arabic of Prémare (1994-1999) for aid in philological and cultural matters.

\section{Frames, script and formulas in ayyu}

It is obvious that four- and sometimes two-line text almost never allows for the development of the intricate complex frames (or themes) we find in sophisticated literary texts (Stockwell 2002) or epic poetry, such as «the assembly», «writing a letter» or «summoning wedding guests» in Serbian epics, which require several dozen lines to fully be developed and woven into a bigger story (Lord 1960). Themes in Jebli poetry are somewhat allusive and rarely talk about concrete actions. A Jebli quatrain can be compared to a small book, made of a cover with a title

(2) On the role of such lines, also known as kläm, please see Gintsburg 2019. 
(frame) and a small, one-page story (script), the two are connected to each other through an association that can often be read and understood only by a member of Jebli society. To explain to the reader how exactly frames and scripts operate in live performance, let us explore an example from the corpus I collected during my fieldwork session that took place in the summer of 2018, during a ziyara (ziyāra), or pilgrimage to the shrine of the local saint Moulay Abdessalam:

a w-ya q̌̌sur al-bayta

Ah and oh, egg shells,

a w-ya q̌̃ūr al-bayța,

Ah and oh, egg shells

a w-sìdi Mūlāy SAbdəssalām

Ah and [I am visiting] my Master Moulay Abdessalam

sāwi dīk al-gayta

[so] play this oboe ${ }^{(3)}$.

It might seem that the first two lines - an image of a peeled egg, or, perhaps, an egg being peeled, or even egg shells left on the ground - have no connection with the remaining two lines of the quatrain. However, this text will be easily understood by any Jebli who has gone on a pilgrimage at least once in his life: he will realise immediately that the poet is here referring to the tradition of having a picnic after visiting the shrine and, of course, eating hard-boiled eggs. We see, therefore, that the theme, or frame of ziyara can be evoked by the image of a picnic and then confirmed through a short story, or script, which is realised by mentioning the name of the saint and re-confirmed by addressing a musician who is participating in this picnic. In other words, from these short four lines, the first two of which repeat each other, we retrieve the following story: a group of people went on a pilgrimage to Moulay Abdessalam, and after they had visited his shrine, they had a picnic, during which pilgrims were eating eggs and exchanging ayyus. Also, in their company they had someone, who knew how to play the traditional oboe.

(3) Almost identical quatrain can also be found in Pereda's collection (Pereda 2014: 155, text 211 and 160 , text 223 ). 
The above example demonstrates that poets who perform within the tradition of the ayyu actively make use of frames, just as is the case for members of other traditions. Although the small size of ayyu, i.e., typically 4 but sometimes even 3 lines, means that the oral, often illiterate Jebli poet does not have enough room to fully explore and develop the potential of frames and scripts, his mind undoubtedly operates the same way as the minds of literate writers and epic poets and, by and large, our Jebli poet resorts to the same cognitive inventory. On the other hand, production, exchange and successful communication within the framework of this genre, where the poet only has a few lines, typically also relies on other resources, such as non-poetic verbal exchange with musicians and audience - words and phrases inserted into the fabric of performance(4), as well as use of temporal and spatial deictics, conjunctions, and interjections ${ }^{(5)}$.

My analysis of the above example thus confirms the idea expressed at the beginning of this paper, namely, that while frames are similar to themes, scripts can be likened to narrative sentences realised through typical set phrases or formulas.

Below I demonstrate some of the most typical frames found in ayyus from the collection by Pereda (2014). It is not the aim of this paper to run an exhaustive analysis of possible frames and scripts that occur in the oral poetry of the Jbala but rather to provide a pilot study, which is meant to serve as an illustration to my ideas. Therefore my analysis will be limited to four frames and the possible scripts associated with each one of them, although a connoisseur of Jebli oral poetry will easily spot numerous examples of other frames.

\subsection{Frame 1} $n w \bar{a} l a^{(6)}$

A hut on top of a hill/mountain -

The image of a mountain with a single thatched dwelling $(n w \bar{a} l a)^{(7)}$ on its top regularly occurs in the oral tradition of the Jbala. This image was identified

(4) Please see footnote 2.

(5) For analysis of use of one such particle in oral Jebli poetry, namely the particle wa-ma - 'and here', please see Gintsburg (2017).

(6) Since it is not the objective of this paper to conduct a philological analysis of the language of ayyus, in most cases I simply copied transcribed Arabic texts without revising them. When I did make changes to the original text or to its translation, I mention that in the footnotes. 
by Moscoso as one of the erotic themes, intrinsic to the tradition of the Jbala, who deciphers this image as phallic (Moscoso 2015a: 58). Although such a reading might appear somewhat far-fetched, it is clear that this image occurs in Jebli poetry with a strong romantic undertone: a small house located in the remote place is seen as an ideal place for an intimate date, for it is not common for the Jbala people to build their houses away from each other, instead, they prefer to settle in hamlets (Salmon 1904: 179, Mikesell 1961: 70-71). On the other hand, in the rural culture of Morocco, nwāla is often used in wedding ceremonies as the place for the first official encounter between between the bridegroom and his bride (Westermarck 1914, 158, 238).

All five examples included in Table 1 contain the same frame, a description of a single dwelling on the top of a hill. However, they also contain further details that are developed in the scripts that will follow. In this case this is information about the place - a particular mountain, such as the mountain of Chafchaouen (presumably the name of the mountain) of Bu Hlal, a mountain next to the town Ouazzane, or just an anonymous high hill.

As mentioned earlier, this frame always evokes scripts related to a love date. Examples 1, 3 and 5 contain scenarios where the main character is expecting his lover, or better to say, seductress (zalläla) to join him in that dwelling and indulge in enjoyment. Example 2 depicts, supposedly, a married woman, who has made the decision to be with her lover, so that now she does not care if her husband divorces her. On the other hand, example 4 suggests a slightly different development of events associated with this frame, namely marriage. This time, the poet first mentions, in a joking manner, the possibility of marriage to a certain girl named Rahma, and then goes further and explains

(7) On the meaning of $n w \bar{a} l a$ in the dialects spoken by the Jbala, please see Prémare (vol. 11: 501). 
that the marriage scenario would never happen ${ }^{(8)}$ by mentioning a tattoo (sayyāla) - a symbol of being a woman, i.e., a gender identifier ${ }^{(9)}$.

Table 1

\begin{tabular}{|c|c|c|c|}
\hline & Arabic & English & Source \\
\hline 1 & 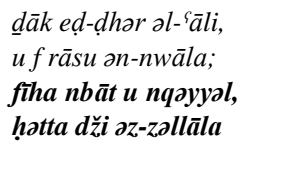 & $\begin{array}{l}\text { That high hill, } \\
\text { And there is the hut on its top. } \\
\text { In it I pass my days and nights, } \\
\text { Waiting for the woman of pleasure } \\
\text { to come }\end{array}$ & 29 \\
\hline 2 & 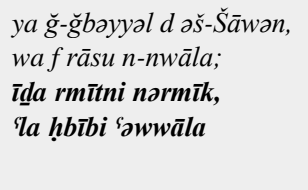 & $\begin{array}{l}\text { Oh the mountain of Chaouen, } \\
\text { And there is a hut on its top. } \\
\text { If you leave me, I will also leave you, } \\
\text { I have decided to be with my } \\
\text { sweetheart. }\end{array}$ & 91 \\
\hline 3 & 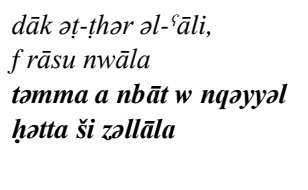 & $\begin{array}{l}\text { That high hill, } \\
\text { And there is a hut on its top. } \\
\text { There I pass my days and nights, } \\
\text { Waiting for the woman of pleasure } \\
\text { to come }\end{array}$ & 252 \\
\hline 4 & $\begin{array}{l}\text { ăg-ğbəl d a š-Šāwan, } \\
\text { f rāsu n-nwāla; } \\
\text { illa notzəwwžək a Roḥma, } \\
\bar{a}^{\varsigma} \text { mol as-sayyāla }\end{array}$ & $\begin{array}{l}\text { Oh mountain of Chaouen, } \\
\text { And there is a hut on its top. } \\
\text { If I marry you, ah Rahma, } \\
\text { I will make myself a tattoo. }\end{array}$ & 432 \\
\hline
\end{tabular}

(8) Pereda and Moscoso translate the lines īla nətzəwwžək a Raḥma, /ā'məl as-səyyāla as «if I marry you, Rahma, / You will make yourself a tattoo». However, I suggest a slightly different interpretation that I base on the following saying I found in Prémare: rāna mra b as-siyyāla - (si je ne fais pas telle chose) «je ne suis qu'une femme au menton tatoué, je ne suis plus un homme» (Prémare vol. 6: 268). Therefore, I understand the above lines as «if I [ever] marry you, Rahma / I will make myself a tattoo (I will not be a man anymore, or, I will not be what I am)».

(9) Tattoos appear to be more associated with the Rifian culture, than the pure Jebli one. However, in the relatively recent past female members of large tribes of mixed origin, such as Fahs, often used to have such tattoos (Salmon 1904: 175-176). On the the role of tattoos in the traditional society in Morocco in general see Searight 1984. 


\begin{tabular}{|l|l|l|l|}
\hline & Arabic & English & Source \\
\hline $\mathbf{5}$ & $\begin{array}{l}\text { a ya Žbal Būhlāl, } \\
\text { ma fi rāsu nŭwwāla } \\
\text { tomma nbāt wa nqayyal, } \\
\text { ga ìla ď̈i z-zollāla. }\end{array}$ & $\begin{array}{l}\text { Ah, the mountain of Buhlal, } \\
\text { And here, there is a hut on its top. } \\
\text { There I pass my days and nights } \\
\text { Until the moment the woman of } \\
\text { pleasure comes. }\end{array}$ & 539 \\
\hline
\end{tabular}

\subsection{Frame 2}

Flying of a tame dove - lwāt / țār / 'lla l-ḥmām / hmmāma

This image represents a common frame that regularly occurs not only in ayyus but in the Jbala poetic tradition in general (Gintsburg 2006). In Pereda's collection alone there are six texts that contain references to the image of a flying dove $\mathrm{e}^{(10)}$. It should be noted that in many other cultures and traditions the image of a dove has a positive, often divine connotation, and the tradition of the Jbala is no exception to this rule. According to Westermarck, while a tame dove - hmmāma, (coll. pl. h̆mām) does not have any specific qualities, a wild dove - yamāma, is seen as: (1) a holy bird, (2) a herald of the reaping season, (3) and even a šri f or fqīr, or a saint ${ }^{(11)}$. (Westermarck 1926 vol II: 337-338). Prémare, in his turn, notes that in the Moroccan vernacular poetry of malhūn a tame dove always plays the role of a messenger, or a symbol of a love couple (Prémare 1994 Vol. 3: 238) ${ }^{(12)}$.

All six examples included in Table 2 contain the same frame - the image of a flying dove. However, this frame in each case is complemented with additional information, such as how, when and why the dove flies, where he lands and even what emotions were caused by the dove's flight.

(10) There are other texts in this collection that contain the word hmām or hmāma «dove», however, I believe that they are elements of different frames, such as «beauty of doves» (Pereda 2014: 167, text 242), «doves sleeping on the mountain» (Pereda 2014, 279 (text 559), or «two doves living on the mountain» (Pereda 2014: 94, text 51 and 287, text 582).

(11) Although this particular meaning was registered by Westermarck is related to the wild dove, I see it important to mention it well as well because in Jebli poetry the mage of a tame dove (hmāma) can also be associated, although indirectly, with the image of a local saint (Pereda 2014: 94, text 51 and 201, text 339).

(12) The image of a tame dove as a messenger and a lover is popular in the modern Jebli poetry as well, especially in the poetic texts by already mentioned here Mohammed Laaroussi. For examples of such texts, see Gintsburg (2005, 2006 and 2014). 
Earlier observations by Prémare and Westermarck are in accord with the Jebli poetic tradition, where the frame «flying dove» evokes only scripts associated with romantic relationships, and the dove is assigned the mixed role of the beloved one and the messenger. For instance, this is the case with example (7), the flying doves (presumably, two doves), wetted their wings in the water, that is to say, they did something unusual, perhaps, even dangerous, so that we are already prepared for a scenario that will contain an element of surprise in it. Indeed, the poet then explains that the man who is not capable of keeping his word does not deserve to be called a man ${ }^{(13)}$. Similarly, in example (4) it is not clear if the dove who got off the ground, flew up and then landed on a dome in Fes is a messenger or rather the beloved one, a certain Allal, who is then compared to a rose in a glass. And in contrast, in example (3), the poet indicates implicitly that the dove is a messenger between him and a certain girl, who has sent to the poet her message - klām- wrapped in her scarf.

Table 2

\begin{tabular}{|c|c|c|c|}
\hline & Arabic & English & Source \\
\hline 1 & $\begin{array}{l}\text { tolwāt d ol-ḥmām, } \\
\text { tolwāt d ol-ḥmām; } \\
\text { ol-bnāt Toțwān, } \\
\text { ŏg-ğīn golla l-kmām. }\end{array}$ & $\begin{array}{l}\text { Doves are dancing in air, } \\
\text { Doves are dancing in the air. } \\
\text { [And] girls from Tetouan } \\
\text { [their] pockets are more expensive than sleeves. }\end{array}$ & 145 \\
\hline 2 & 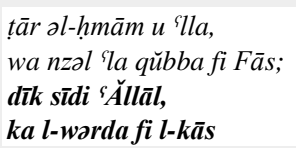 & $\begin{array}{l}\text { The dove got off the ground and flew up, } \\
\text { And he landed on a dome in Fes. } \\
\text { That sidi Allal } \\
\text { Is [handsome] like a rose in a goblet. }\end{array}$ & 339 \\
\hline
\end{tabular}

(13) The image of a bird that wetted its wings in the water appears to be strongly associated in the metaphorical language of the Jbala with romance. Consider, for instance, the following proverb: l-xottaif el-bahri rxa jnāhu ne l-ma dāk l-Sayūn farqūni Sala l-yemma, «the sea-gulls lowered their wings to the water, those black eyes separated me from my mother» (WestermarcK 1931, 81). 


\begin{tabular}{|c|c|c|c|}
\hline & Arabic & English & Source \\
\hline 3 & 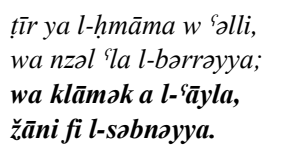 & $\begin{array}{l}\text { Get off the ground, oh, dove and fly up, } \\
\text { And land on a the oleaster tree. } \\
\text { Your message, oh, girl, } \\
\text { Reached me [wrapped in scarf]. }\end{array}$ & 514 \\
\hline 4 & 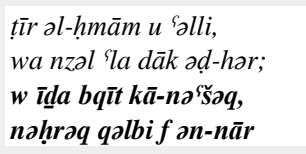 & $\begin{array}{l}\text { Get off the ground, oh, dove, and fly up, } \\
\text { And land on the hill. } \\
\text { And if I continue loving [you], } \\
\text { I will burn my heart in fire. }\end{array}$ & 524 \\
\hline 5 & $\begin{array}{l}\text { ol-ḥmāma 'allāt a žnāḥu, } \\
\text { w āna qalbi ġār } \\
\text { ol-ḥmāma 'ollāt a žnāhu, } \\
\text { w àna rūhịi țār }\end{array}$ & $\begin{array}{l}\text { The dove flew up on its wings } \\
\text { And my heart became jealous. } \\
\text { The dove flew up on its wings } \\
\text { And my soul took off [as well]. }\end{array}$ & 636 \\
\hline 6 & 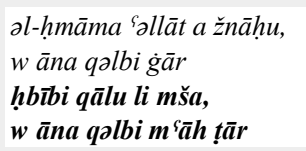 & $\begin{array}{l}\text { The dove flew up on its wings } \\
\text { And my heart became jealous. } \\
\text { They told me that my beloved one has } \\
\text { gone/and with him has gone my heart. }\end{array}$ & 646 \\
\hline 7 & $\begin{array}{l}\text { ol-ḥmām țāru, } \\
\text { wa rxāw žnāhŭm l al-ma; } \\
\text { w əlli xərrož ol-'shd } \\
\text { ma rāžol ysamma. }\end{array}$ & $\begin{array}{l}\text { The doves were flying } \\
\text { And wetted their wings in the water. } \\
\text { The one who does not keep his word } \\
\text { Cannot be called a man. }\end{array}$ & 348 \\
\hline
\end{tabular}

\subsection{Frame 3}

Tray with tea-glasses on it - s-siniyya w l-kīsān

This frame depicts an image of a tray with a glass (glasses) on it. The tradition of serving tea in small glasses on a tray is typical not only in the Jbala region but throughout the Moroccan Kingdom. Therefore, the image of a tray with tea glasses placed on it is deeply embedded in the culture. It should not be surprising, then, that additional cultural and anthropological information would be required in order to better understand what associations on the cognitive level can be evoked by this frame. Westermarck, for instance, reads the event of drinking tea as implying pleasure, to the degree that tea cannot be offered at a 
funeral (Westermarck 1926 vol 2: 467). In relation to the tray, the same author notes that, typically, the image of an empty tray has a negative connotation and is to be avoided (Westermarck 321), while the image of a full tray sets up positive expectations - of family reunion, perhaps, a love date, or even a wedding, a gathering with friends, or secret flirting. On the symbolical level, Moscoso offers an interesting explanation as well, he also suggests this should be read as an erotic symbol (Moscoso 2015a: 58).

All seven examples included in Table 3 contain the frame of the tray with glasses, which is complemented with other relevant details that will later contribute to further development of the story. This image can be complemented with a metal kettle, as is the case in example (7), or contain other relevant details, such as silver glasses in example (1), shiny glasses in example (5), or metal glasses in example (3). In example (4) general information supplied by this frame is supplemented with the further precision - the poet mentions the giver of glasses, who, nevertheless, did not give with them the tray, the key element of the tea drinking ceremony, where the host of the house serves readyprepared hot tea in a tea-kettle, which is placed on a tray together with small glasses made of glass or metal.

This frame, therefore, activates several scripts: while some seem to represent a positive scenario, others are not so optimistic. For instance, the script from example (1) paints the picture of a man, who plans to enjoy the beauty of a woman whom he asks to prepare tea, and the script in example (6) also depicts a similar scene - that of flirting between a man and a young woman who serves him his tea. On the other hand, the frame activates not only scripts of further celebrating, flirting and joking, it can also evokes scenarios that describe what is going to follow after tea-drinking - a involuntary trip to some local authorities, as is the case in example (3) or an unfair accusation made by the same authorities ${ }^{(14)}$, as the script from examples (2) and (7) suggests. With the exception of example (7), where the poet mentions not only the tray with glasses but also a tea-kettle, it is not indicated directly that the tray with glasses

(14) Mentioning of maxzən or any other authorities often sends us back to the colonial past, i.e., the time, where Pereda collected these poems. Although traditional Jebli poets avoid criticising authorities directly, through their poems protrudes the general attitude of Jebli people toward the role of maxzon in their lives, which is seen an an unjust but necessary body that can control their lives only in a limited way. 
is meant for drinking tea and not other substances, for instance, local grape wine, șāmot, and drinking wine collectively from glasses during fräjas, or parties, was until recent times a common practice ${ }^{(15)}$.

Interestingly, in example (4) the same frame gives birth to an ironic script: in this case, the theme of tea drinking has a humorous element implanted in it: the poet says that while there are glasses, the tray, i.e., the key element, is missing ${ }^{(16)}$, and he then shifts to Mulay Ahmed Raisouni (mūlayy Ahməd ərRaysüni) ${ }^{(17)}$, the symbolic political figure of Jebli origin and a šrîf, or descendant of the Prophet who lived during the époque of the Protectorate, and mentions that he has married a woman from the plains ${ }^{(18)}$.

Table 3

\begin{tabular}{|c|c|c|c|}
\hline & Arabic & English & Source \\
\hline 1 & $\begin{array}{l}\text { qīmu li es-sīnəyya, } \\
\text { qīmu lha ya l-kīsān; } \\
\text { w āna nomši a z-zayn, } \\
\text { mūl az-zhu w as-salwān. }\end{array}$ & $\begin{array}{l}\text { Prepare for me a tray, } \\
\text { Prepare for me glasses. } \\
\text { So that I will go, oh, beauty } \\
\text { Happy and content }\end{array}$ & 71 \\
\hline 2 & 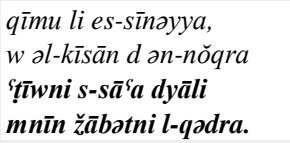 & $\begin{array}{l}\text { Prepare for me a tray } \\
\text { And glasses made of silver. } \\
\text { Give me a chance, } \\
\text { No matter where my fate would then take me }\end{array}$ & 72,598 \\
\hline
\end{tabular}

(15) See, for instance, the account of Michaux-Bellaire on the Jebli tradition of consuming alcohol (Michaux-Bellaire 1911: 149-150 and 220-227). In addition, references to the practice of drinking wine can also be found in songs by the famous Jebli poet and musician Mohamed Laaroussi (1934-2014) (Gintsburg 2005: 2006).

(16) Comparing marriage to a tea set is common in Jebli metaphorical language. It is done on the principle of a missing key element, without which the final product will not be complete. Consider the following proverb: j-jwāj bla niya bhāl l-berrād bla sīniya, «marriage without good faith is like a tea-pot without a tray» (Westermarck 1931: 77).

(17) For detailed information on Raisouni, see, for instance, Tessainer \& Tomasich 1999.

(18) The Jeblis generally have a negative attitude toward Carūbi people, i.e., people from the plains adjacent to the region of the Jbala (westermarck 1926 vol 1: 4-6 and Michaux-Bellaire 1911: 13-22). 


\begin{tabular}{|c|c|c|c|}
\hline & Arabic & English & Source \\
\hline 3 & $\begin{array}{l}\text { qīmu li əs-sīnəyya, } \\
\text { b əl-kīsān d a l-mə`dən; } \\
\text { al-mhəkma d rabbi, } \\
\text { ma həyya ši d a l-məxzən }\end{array}$ & $\begin{array}{l}\text { Prepare for me a tray } \\
\text { with metal glasses [on it]. } \\
\text { [Only] Lord can judge me } \\
\text { And not the authorities }\end{array}$ & 189 \\
\hline 4 & 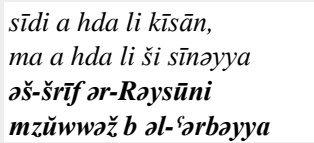 & $\begin{array}{l}\text { My master gave me glasses } \\
\text { But he did not give me a tray [with them]. } \\
\text { The shrif Raisuni } \\
\text { Is married to a woman from the plains }\end{array}$ & 346 \\
\hline 5 & 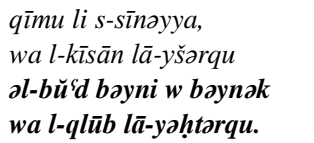 & $\begin{array}{l}\text { Prepare for me a tray, } \\
\text { With shiny glasses [on it]. } \\
\text { There is a distance between you and me, } \\
\text { So our hearts are burning }\end{array}$ & 465 \\
\hline 6 & 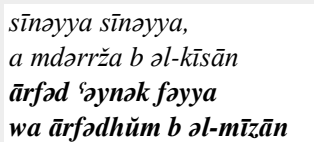 & $\begin{array}{l}\text { Tray, tray, } \\
\text { With glasses placed on it. } \\
\text { Look up a me } \\
\text { And then graciously look down }\end{array}$ & 575 \\
\hline 7 & 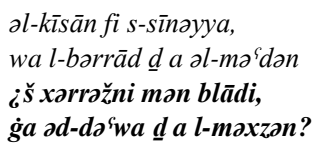 & $\begin{array}{l}\text { There are glasses on the tray } \\
\text { And a metallic kettle. } \\
\text { What could make me leave my land, } \\
\text { If I was not cursed by the authorities? }\end{array}$ & 631 \\
\hline
\end{tabular}

\subsection{Frame 4}

Crop cutting /tawiza - sayfìy / tawiza

This frame is linked to the season of cutting crops, known as sayfiya and the tradition of tawiza. Tawiza or tawaza (tawāza) is a festivity and ritual dedicated to harvesting, where the members of a tribe get together to help each other in the fields, which are usually located outside the village $(d \check{s} a r)^{(19)}$. Typically, tawiza takes place during the harvest season, i.e., in June or July. Men

(19) For further information on the pattern of settlements in the Jbala area, please see Mikesell (1961: 71). 
and women work in separate groups, the men organise themselves in a row and reap with a sickle, while the women, who also organise themselves in a row, walk behind the men and collect wheatears. Sometimes, a small group of musicians is invited to this event, typically, an oboist and a drummer. While working, the women start a poetic conversation in ayyu form. It is not uncommon for men to join this conversation with women or continue it among themselves. About thirty years ago the tradition of tawiza ${ }^{(20)}$ was still very popular in northern Morocco, i.e., both in the Jbala and the Rif regions, but now it has almost disappeared due to the introduction of agricultural machinery, which has replaced practically all collective physical labour activities.

The first two lines of each of the five selected examples included in Table 4 contain the same frame, i.e., about cutting crops and/or participating in tawiza. This frame is then complemented with further details, such as particular characteristics of reapers, weather conditions, etc.

As shown in table 4, this frame evokes several scripts. Scripts from examples (1), (3), (4) and (5) appear to be almost identical, although, as I will demonstrate below, they describe different scenarios. In the script from example (1) the poet (probably, a woman), addresses the reaper in a rather ambiguous way by using the word hhbibi, «my sweetheart», which, however, can also be understood as «my dear friend» (Prémare vol 3: 5-6), and then invites him to come back under the shade of the vine (dall ad-dālya). The script from example (5) practically duplicates script 1 with only one difference - in the script the poet addresses the reaper using the word $ə l-h ̧ s s \underline{a} \bar{a}$, «the reaper» and, therefore, eliminates the possibility of reading this quatrain as an attempt to flirt. In example (3) the poet also talks to reapers but, this time, calls them ș-şyyāfa, «harvesters» (see Prémare vol. $8 ; 152)^{(21)}$ and then invites them under the shade $(d \partial l l)$. In example 4 the poet addresses the reaper (əl-hoss $\bar{a} d)$ and then invites him to return to the fig tree shade ( $\partial \underline{d}$-doll $d$ ol-qarmū $\underline{d}$ ). We see that, generally speaking, all four scripts transmit the same idea: once you cannot work any more (because you are tired or because the sun is too hot), come back [to me/us]

(20) For further information on the custom of tawiza, please see Salmon (1904: 236) and Biarnay (1924).

(21) The terms sayyāf and hasssād have the same meaning and are interchangeable. I use different translations for each only to show the reader that in the original texts Jebli poets used different words and not the same. 
under the shade. However, it is important to pay attention to where, exactly, the above-mentioned shade is located. In the case of examples (1) and (3), the poet refers to a vine, which, most probably, grows in an orchard, or even next to the house, i.e., in the territory located inside the village. In other words, the reapers are told to go back to the village because they need a long break or because the job for today is done. The script from example (3) only mentions shade that can be cast by a tree, domestic animal, or any other properly sized object. Similarly, the script from example (4) refers to the shade of a fig tree, which can grow both in the orchard (domesticated) and in the field (wild) ${ }^{(22)}$. In other words, the poet invites the reapers to have a short break right there in the field and then get back to work, rather than returning to the village.

On the other hand, example (2) offers a different development of events the poet addresses the reapers by asking them to carry on exchanging ayyus and not to stop. The mentioning of ayyus then leads to activation of a different script - that of a broken heart caused either by an unhappy love story, or separation from parents caused by arranged marriage ${ }^{(23)}$.

Table $4^{(24)}$

\begin{tabular}{|c|c|c|c|}
\hline & Arabic & English & Source \\
\hline 1 & 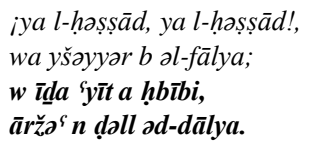 & $\begin{array}{l}\text { Oh, reaper, oh, reaper! } \\
\text { Who cuts a sheaf in one move. } \\
\text { If you feel tired, my sweetheart - } \\
\text { Come back under the vine's shade. }\end{array}$ & 28 \\
\hline 2 & 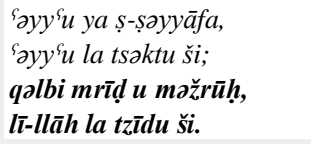 & $\begin{array}{l}\text { Keep exchanging ayyus, oh, harvesters, } \\
\text { Keep exchanging ayyus and do not stop. } \\
\text { My heart is sick and ill - } \\
\text { Please do not make it even worse }\end{array}$ & 83 \\
\hline
\end{tabular}

(22) On the role of domestic and wild fig trees in the Jbala area please see AUMEEREERUDDYTHOMAS, HMIMSA, ATER\& KHADARI (2014, 192-193).

(23) An almost identical script can be found in example (1) in table 2.

(24) I slightly modified the text in examples (4) and (5) in this table. Line 3 of the above examples

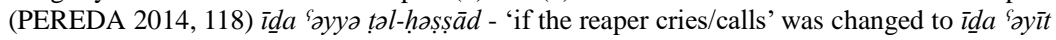
al-ḩsṣẫ - 'if you get tired, reaper' because otherwise the text does not make sense. 


\begin{tabular}{|c|c|c|c|}
\hline & Arabic & English & Source \\
\hline 3 & 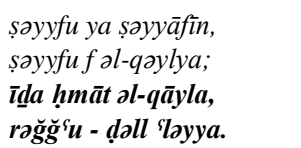 & $\begin{array}{l}\text { Collect the harvest, oh, harvesters! } \\
\text { Keep harvesting under the hot sun of midday. } \\
\text { And if it gets too hot, } \\
\text { Come back under the shade }\end{array}$ & 88 \\
\hline 4 & 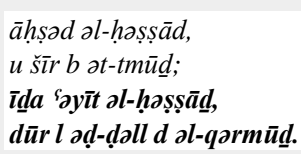 & $\begin{array}{l}\text { Reap, oh reaper, } \\
\text { And let me know when you see kohl lined eyes } \\
\text { And if you feel tired, oh, reaper - } \\
\text { Return under the fig tree's shade }\end{array}$ & 114 \\
\hline 5 & 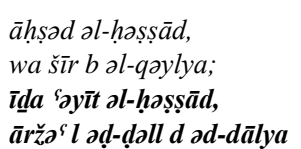 & $\begin{array}{l}\text { Reap, oh reaper, } \\
\text { And let me know when it gets too hot. } \\
\text { And if you feel tired, oh, reaper - } \\
\text { Come back under the vine's shade }\end{array}$ & 115 \\
\hline
\end{tabular}

\section{Conclusion}

In this paper I demonstrate that cognitive linguistic categories, such as frames and scripts, help to shed light on oral improvisational poetry, in this case, the ayyu - a living oral poetic tradition of the Jbala. I based my research on the poetic quatrains from the collection by Pereda (2014). Following recent research mainly focused on written authored texts and the ancient Greek epics, I proceeded from the assumption that in oral poetry frames can be seen as themes and topics and suggested that, in this case, frames are operationalised in scripts, that is, sequences of narrative or discursive development. By analysing four popular frames typical of Jebli poetry, namely (1) a hut on top of a hill / mountain (dhar / $\breve{g}$-ğboyyal / $\breve{g}$-ğbal f rāsu on-nwāla), (2) the flight of a tame dove (lwāt /țār / Illa lhmām / hmāma), (3) a tray with tea-glasses on it (s-siniyya w l-kīsān), and (4) harvesting crops / tawiza (sayfiya / tawīza), I demonstrated that frames trigger particular linguistic realisations, i.e., fixed or semi-fixed formulas that, in their turn, reveal certain scripts that underlie the organisation of these poems. Such «ready-made» expressions have become conventional within the genre and social setting, performing an important role in creating empathy and solidarity within the cultural group (Fillmore, 1997). As this research has demonstrated, both the scripts and the formulas appear to be relatively stable, and evidently form part of a living poetic tradition into which the individual singers have been socialised, and 
which shapes the expectations of their audiences. But importantly, these scripts and formulas also display a degree of openness to variation. Anonymous Jebli oral poets who perform in the genre of ayyu produce their verses spontaneously in front of a live audience who are familiar with the genre and its constraints. Moreover, the genre also often implies a form of poetical dialogue, i.e., the audience not only understands the meaning of the uttered verse but is also prepared to reply to it in a similar manner. Therefore, the poets' task is to satisfy the audience's expectations by producing something individual or different within that limited framework - and importantly, also giving space to others to act as poets and produce their own poetry.

In addition, it is clear that learning more about how such genres operate from a cognitive perspective can help us to better understand the evidence concerning the oral genres of the past. Just as the Jebli poet learns, applies and varies a set of scripts and formulas in association with particular frames (in this case, themes), so the epic poets of the past are likely to have applied a combination of memorisation, spontaneous adaptation and innovation to weave their intricate narratives around their frames (events or incidents). The use of scripts and formulas certainly reduces the cognitive load on the poet and enables real-time performance. Moreover, when the audience is also familiar with the genre, the use -and creative adaptation- of these stock elements helps comprehension and builds a sense of community.

Finally, I have illustrated how a cognitive reading of the ауyи requires a solid knowledge of the context: without knowing this particular culture, being physically present during the performance and even knowing in person the performer it would be difficult to grasp the meaning of Jebli quatrains. In other words, although frames and, hence, scripts can be universal, they are also often culturally embedded, and to achieve a full understanding of them we need to take into account the social role and enactment of the genres, the background culture, as well as the singer's gender, age, current life situation and many other factors. 


\section{REFERENCES}

AUMEERUDDY-THOMAS, Yildiz, HMIMSA, Younes, ATER, Mohammed \& KHADARI, Bouchaib. 2014. «Pertaining to Fig (Ficus carica L.) and Olive (Olea europaea L.) Agroecosystems Among Jbala Communities in Northern Morocco». In: Patricia Anderson \& Leonor Peña-Chocarro (eds.). Early Agricultural Remnants and Technical Heritage (EARTH): 8,000 Years of Resilience and Innovation. Oxford, Oxbow books, pp. 191197.

BARTLETT, Frederic. 1932. Remembering. Cambridge, Cambridge University Press.

BIARNAY, Simon. 1924. Notes d'ethnographie et de linguistique nordafricaines. Paris, Ernest Leroux.

BOAS, Hans. 2016. «Frames and constructions for the study of oral poetics». In: Mihailo Antović \& Cristóbal Pagán Cánovas (Eds.). Oral Poetics and Cognitive Science. Berlin, De Gruyter, pp. 99-124.

BOZZONE, Chiara. 2014. Constructions: a New Approach to Formularity, Discourse, and Syntax in Homer. <http://escholarship.org/uc/item/6kg0q4cx.pdf> [09/30/2019].

COCKROFT, Robert. 2002. Renaissance Rhetoric: Reconsidered Passion - The Interpretation of Affect in Early Modern Writing. London, Palgrave.

COOK, Guy. 1994. Discourse and Literature. Oxford, Oxford University Press.

DE KREIJ, Mark. 2016. «The Priming Act in Homeric Epic». In: Mihailo Antović \& Cristóbal Pagán Cánovas (eds.). Oral Poetics and Cognitive Science. Berlin, De Gruyter, pp. 148-167.

FILLMORE, Charles. 1982. «Frame semantics». In: Linguistic Society of Korea (ed.). Frame Semantics in Linguistics in the Morning Calm. Seoul, Hanshin Publishing Company, pp. 111-137.

GARCÍA RUDA, Julio. 2016. La música de los iqeroayen del Rif (Marruecos). <https://eprints.ucm.es/38208/1/T37419.pdf> [11/10/2019].

GINTSURG, Sarali. 2005. «Seven Folk Songs from the Region of the Jbala (Northern Morocco)». Acta Orientalia 66, pp. 73-107.

GINTSBURG, Sarali. 2006. «Some observations on the poetical language of love songs in the dialect of the Jbala (Northern Morocco)». al-Andalus Magreb 13, pp. 139-161. 
GINTSBURG, Sarali. 2014. Formulaicity in the Jbala poetry. Tilburg, Tilburg University Press.

GINTSBURG, Sarali. 2017. «It's got some meaning but I am not sure...: The role of the particle (wa)-ma in the oral and transitional poetry of the Jbala (northern Morocco) from the cognitive perspective». Pragmatics \& Cognition 24, 3, pp. 474-495.

GINTSBURG, Sarali. 2019. «Lost in dictation. A cognitive approach to oral poetry: Frames, scripts and 'unnecessary' words in the Jebli ayyu». Language \& Communication 64, pp. 104-115.

LORD, Albert. 1960. The Singer of Tales. Cambridge, Harvard University Press.

MICHAUX-BELLAIRE, Édouard. 1911. «Quelques tribus de la montagnes de la région du Habt». Archives marocaines 17. Paris, Ernest Leroux.

MIKESELL, Marvin. 1961. Northern Morocco, a cultural geography. Berkley $\&$ Los Angeles, University of California Press.

MINSKY, Marvin. 1975. «A framework for representing knowledge». In: Patrick Winston (ed.). The Psychology of Computer Vision. New York, McGraw-Hill, pp. 211-277.

MOSCOSO GARCÍA, Francisco. 2015a. «Coplas de Chauen (norte de Marruecos). Temática y lenguaje formulaico». Boletín de Literatura Oral 5, pp. 45-68.

MOSCOSO GARCÍA, Francisco. 2015b. «El lenguaje formulaico en las coplas de la región de Yebala, Marruecos». Revista de literaturas populares XV1, pp. 135-166.

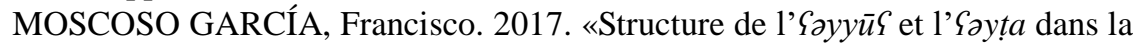
région de Jbala : métrique et rime». In Hafida El Amrani, Leïla Messaoudi, Ali Reguigui \& Hanane Bendahmane (eds.). Pluridisciplinarité en Sciences Humaines: Hommage à Leila Messaoudi. Sudbury, Université Laurentienne, Département d'études françaises, pp. 83-95.

PEREDA ROIG, Carlos. 2014. Coplas de la región de Yebala: norte de Marruecos. Estudio y edición de Francisco Moscoso García. Barcelona, Bellaterra.

PRÉMARE, Alfred-Louis de. 1994-1999. Dictionnaire arabe-français (établi sur la base de fichiers, ouvrages, enquêtes, manuscrits, études et documents divers par A. L. de PRÉMARE et collaborateurs), vols. I-XII. Paris, L'Harmattan. 
SALMON, George. 1904. «Une tribu marocaine - Les Faḥçya». Archives Marocaines I, pp. 149-261.

SCHANK, Roger \& ABELSON, Robert. 1977. Scripts, Plans, Goals, and Understanding: An Inquiry into Human Knowledge Structures. Hillsdale, Lawrence Erlbaum.

SEARIGHT, Susan. 1984. The use and function of tattooing on Moroccan women. 3 vols. New Haven (P.O. Box 2015, Yale Station, New Haven 06520), Human Relations Area Files.

STEEN, Gerard. 2003. «Love stories: cognitive scenarios in love poetry». In Joanna Gavins \& Gerard Steen (eds.). Cognitive Poetics in Practice, London, Routledge, pp. 67-82.

STOCKWELL, Peter. 2002. Cognitive poetics. An introduction. London \& New York, Routledge.

TESSAINER y TOMASICH Carlos. 1998. El Raisuni, aliado y enemigo de España. Málaga, Algazara.

WESTERMARCK, Edward. 1926. Ritual and Belief in Morocco. 2 vols. London, Macmillan and Co.

WESTERMARCK, Edward. 1914. Marriage ceremonies in Morocco. London, Macmillan and Co.

WESTERMARCK, Edward. 1931. Wit and wisdom in Morocco. A Study of Native Proverbs. London, George Routledge \& Sons, Ltd. 